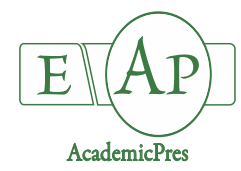

Rajičić V et al. (2020)
Notulae Botanicae Horti Agrobotanici Cluj-Napoca 48(4):2134-2152
DOI:10.15835/48412106
Research Article

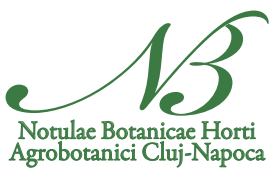

\title{
Impact of lime and NPK fertilizers on yield and quality of oats on pseudogley soil and their valorisation
}

\section{Vera RAJIČIĆ ${ }^{1 *}$, Vera POPOVIĆ ${ }^{2 *}$, Dragan TERZIĆ ${ }^{1}$, Dragan GRČAK ${ }^{3}$, Marijana DUGALIĆ ${ }^{1}$, Andreja MIHAILOVIĆ ${ }^{4}$, Milosav GRČAK ${ }^{3}$, Vladan UGRENOVIĆs}

\author{
${ }^{1}$ University of Niš, Faculty of Agriculture, Kosančićeva 4, 37000 Kruševac, Serbia; verarajicic@yahoo.com (*corresponding author) \\ dragan.terzic.agro@gmail.com; marijanadugalic80@gmail.com \\ ${ }^{2}$ Institute of Field and Vegetable Crops, Maksima Gorkog 30, 21000 Novi Sad, \\ Serbia; drvvpopovic@gmail.com ("${ }^{*}$ corresponding author) \\ ${ }^{3}$ University of Priština-Kosovska Mitrovica, Faculty of Agriculture, Kopaonička bb, 38228 Lešak, \\ Serbia;dragangrcak@gmail.com; milosavgrcak@gmail.com \\ ${ }^{4}$ University of Montenegro, Faculty of Law, 2 July 13, 81000,Podgorica, Montenegro; deamihailovic@gmail.com \\ ${ }_{5}^{5}$ Institute of Soil Science, Teodora Drajzera 7, Belgrade, Serbia; vladan.ugrenovic@gmail.com; bravera@eunet.rs
}

\begin{abstract}
In order to determine the effect of fertilization, environment, and their interactions on the yield and oats yield components. Five fertilization treatments (T1-control, T2-80 $\mathrm{kg} \mathrm{N}^{-1}, \mathrm{~T} 3-120 \mathrm{~kg} \mathrm{~N} \mathrm{ha}^{-1}, 80 \mathrm{~kg}$ $\mathrm{P}_{2} \mathrm{O}_{5} \mathrm{ha}^{-1}$ and $80 \mathrm{~kg} \mathrm{~K}_{2} \mathrm{O} \mathrm{ha}^{-1}$, T4- $\mathrm{N}_{120} \mathrm{P}_{80} \mathrm{~K}_{80}+5 \mathrm{t} \mathrm{ha}^{-1}$ of lime and $\mathrm{T} 5-\mathrm{N}_{120} \mathrm{P}_{80} \mathrm{~K}_{80}+5 \mathrm{t} \mathrm{ha}^{-1}$ of lime $+30 \mathrm{t} \mathrm{ha} \mathrm{a}^{-1}$ of farmyard manure) were examined during three growing seasons in Kraljevo location in Western Serbia. Grain yield (GY), 1000 grain weight (TGW), hectolitre weight (HW), plant height (PH), panicle length (PL), number of grains per panicle (NGP) and protein content (PC) were analysed. The aim of the study was to determine the effect of organic and mineral fertilization and calcification on the yield and oats yield components. On average, for all fertilizer variants, during the three-year trial, the highest yield of oats $3802 \mathrm{~kg}$ $\mathrm{ha}^{-1}$ was obtained in the fertilizer variant with the combined application of NPK fertilizers, lime and manure. Positive highly significant correlation, during in the study trial were found between yields with PH, PL and NGP. Negative and highly significant dependencies were found between protein content with GY, PH and NGP. The results of these studies indicate the importance of rational introduction of adequate quantities of fertilization, calcification and humization in order to make oats as profitable as possible in the agro-ecological conditions in Pannonian Environments.
\end{abstract}

Keywords: farmyard manure; fertilizer; grain quality; lime; oats; protein content; yield

\section{Introduction}

Oat is a plant species that has significantly less fertilization requirements than other small grains. This plant species has a higher power of absorbing nutrients from soils that are not fit for cultivation of wheat, such as acidic soils, as well as other poor soils of marginal value. In recent years, total production and areas under 
oats, both in the world (Khan et al., 2014) and in the Republic of Serbia (Jelic et al., 2013), have been diminishing sharply. Today, in the world, according to FAO data, in 2018, oats is grown annually on an area of 9.85 million ha, with an average yield of $2.341 \mathrm{t} \mathrm{ha}^{-1}$, while in the Republic of Serbia it is cultivated on an area of 26.111 ha, with a slightly higher yield $2.861 \mathrm{t} \mathrm{ha}^{-1}$ (FAO, 2020).

Oat fertilization is a very important technological operation for achieving high grain yields. Oats uses very hard soluble nutrients from the soil very well. It responds well to fertilization, especially nitrogen (MonjeziZadeh et al., 2018; Vasileva and Kostov, 2018). With the application of optimal amounts of fertilizer on most soils, oats give high grain yields (Nawaz, 2017). Oat plants are a major consumer of nitrogen and potassium, however, when fertilizing with nitrogen, caution should be exercised as stronger crop lodging can occur (Tomple and Hwan, 2018). Starting from the stated yield standards of $3.0 \mathrm{t} \mathrm{ha}^{-1}$ of grain, Jelic et al. (2013), point out that about $80 \mathrm{~kg} \mathrm{ha}^{-1}$ of nitrogen should be used; $40-50 \mathrm{~kg} \mathrm{ha}^{-1}$ of phosphorus and about $40 \mathrm{~kg} \mathrm{ha}^{-1}$ of potassium.

Due to the good intake power of the root, oats make excellent use of nutrient residues after the preharvest crop and in crop rotation it often comes last, however, high grain yields cannot be expected in such crop rotation. The requirements of oats in relation to soil compared to other cereals, except rye, are modest (Zielinski et al., 2017). Although it thrives on poorer soils with slightly reduced yields, oats nevertheless achieve higher yields on more fertile lands (Tomple and Hwan, 2018). Panasievicz et al. (2017), find that nitrogen application significantly affects the protein content of oat grains, especially when using large doses of this nutrient (100 and $150 \mathrm{~kg} \mathrm{~N} \mathrm{ha}^{-1}$ ). Many authors point out that different oat genotypes (winter and spring) differ in chemical composition, and especially in protein content (Amanullah and Stewart, 2013; Khan et al., 2014; Mut et al., 2018). The quality and chemical composition of oat grains are closely related to the fertility of this crop species, which is a significant feature in terms of the cost-effectiveness of its cultivation in general and its use as a forage plant (Jelic et al., 2013; Brunava et al., 2014; Jordanovska et al., 2018).

Although oats have a stretched and relatively uniform rhythm of nutrient uptake during vegetation, most nutrients are still required during stem elongation and in the panicle occurrence phase (Mahadevana et al., 2016). Thus, the amounts of applicable nitrogen, phosphorus and potassium nutrients depend on the resistance of the cultivated oat varieties to crop lodging and low temperatures, soil fertility, soil physical properties, agro-ecological conditions of the area, planned yield and economic power of the producer (Maral et al., 2013; Krishna et al., 2014; Zielinski et al., 2017; Devi et al., 2019; Szatanik-Kloc et al., 2019). For high yields of oats, complex NPK fertilizers need to be introduced with the prolonged action of manure applied for the preceding crop (Jelic et al., 2013).

In the Republic of Serbia, especially in its central part, the production of cereals is mainly carried out on soils with acidic and extremely acidic reactions, low quality structures that are poor in organic matter (Jelic and Milivojevic, 2015). On acid reaction soils, a universal fertilization system does not exist due to the very uneven physical and chemical properties of these soils. Therefore, the application of fertilizers on acid soils must be approached in a much more rational and multi-faceted manner.

Bearing in mind the necessity of applying pedomeliorative measures and the use of larger quantities of fertilizers on acid soils, there is a need to review and modify the existing fertilization systems. For these reasons, the aim of the study was to determine the effect of the application of different fertilization variants (NPK, lime, and manure) on the yield parameters and quality of oat grains on pseudogley soil. In addition, the aim of the research was to determine the optimal use of fertilizers to achieve profitable production of oats in the Western Serbia region. 


\section{Materials and Methods}

\section{Experimental design}

Field experiments were performed on the experimental field of the secondary agricultural-chemical

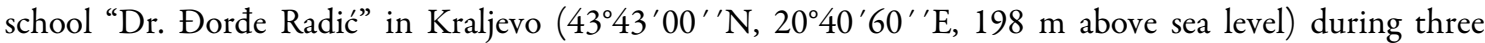
growing seasons $(2015,2016$ and 2017) in dry crop conditions, with the aim of analysing the yield and quality of oat grains in Western Serbia. Trials were arranged according to a randomized scheme in five repetitions. Trial treatments included different fertilization variants: T1-control, T2-80 kg N ha ${ }^{-1}$, T3-NPK $(120 \mathrm{~kg} \mathrm{~N} \mathrm{ha}$ ${ }^{1}, 80 \mathrm{~kg} \mathrm{P}_{2} \mathrm{O}_{5} \mathrm{ha}^{-1}$ and $80 \mathrm{~kg} \mathrm{~K}_{2} \mathrm{O} \mathrm{ha}^{-1}$ ), T4- $\mathrm{N}_{120} \mathrm{P}_{80} \mathrm{~K}_{80}+5 \mathrm{t} \mathrm{ha}^{-1}$ of lime and T5- $\mathrm{N}_{120} \mathrm{P}_{80} \mathrm{~K}_{80}+30 \mathrm{t} \mathrm{ha}^{-1}$ of manure $+5 \mathrm{t} \mathrm{ha}^{-1}$ of lime (factor A) and different growing seasons: $\mathrm{Y}_{1}-2015, \mathrm{Y}_{2}-2016$ and $\mathrm{Y}_{3}-2017$ years (factor B). NPK fertilizer formulation (15:15:15) was used in the experiment in pre-sowing soil preparation. In early March 2015, non-hydrated $\mathrm{CaO}$ lime, $99 \%$ pure, was applied for calcification of the soil and incorporated at a depth of $30 \mathrm{~cm}$. The spring oat has been preceded by maize in all seasons. During the vegetation period of oats to protect crops from Lema melanopus L. was used preparation Fastac 10 EC $\left(0.151 \mathrm{ha}^{-1}\right)$. Fertilization was carried out in 2-3 leaf stage, and nitrogen was applied in the form of ammonium nitrate (AN, 33\% N).

The area of the elementary plot was $500 \mathrm{~m}^{2}(25 \mathrm{~m} \times 20 \mathrm{~m})$. The spring oat variety Slavuj originating from the Kragujevac Centre for Small Grains was selected as the material for the experiment. The sowing was performed within the optimum agrotechnical period (March 10, 2015, March 7, 2016, and March 11, 2017) at $12 \mathrm{~cm}$ row spacing, with a sowing density of 500 germinating grains per $\mathrm{m}^{2}$. The trial was designed in randomized blocks with five replications. Conventional production technology was applied. The crops were harvested at full maturity stage (dates of harvesting 10 July 2015, 6 July 2016 and 14 July 2017) and the grain yield $\left(\mathrm{GY}, \mathrm{t} \mathrm{ha}^{-1}\right), 1000$ grain weight (TGW, g), hectolitre weight (HW), plant height (PH), panicle length (PL), number of grains per panicle (NGP) and protein content (PC) were quantified. Grain yield was measured for each plot and converted to grain yield in $t \mathrm{ha}^{-1}$ based on $14 \%$ grain moisture, after which a sample was taken for analysis of TGW, HW and PC of the grain. Thousand grain weight was determined using an automatic seed counter. Hectolitre weight was determined by a Schoper's scale, 0.251 capacity. The Kjeldahl method was used to determine the nitrogen content of the oat grain, while the crude protein content of the grain was obtained by multiplying the total nitrogen by a factor/coefficient of 6.25 . Immediately before harvest, a sample of 20 plants was taken from each plot to determine PH, PL and NGP. Standard grain sampling techniques were used in the research.

\section{Soil analysis}

The trial was performed on pseudogley soil, of unfavourable physical characteristics, of poor water-air regime with frequent water or air deficiencies. According to the results of agrochemical analysis, the soil is acidic ( $\mathrm{pH}$ in $\mathrm{H}_{2} \mathrm{O} 5.42$ and $\mathrm{pH}$ in $\mathrm{KCl} 4.46$ ), poor in humus (2.19\%), poor in available phosphorus $\left(<10 \mathrm{mg} 100^{-1} \mathrm{~g}\right.$ of soil) and medium provided with readily available potassium $\left(13-18 \mathrm{mg} 100^{-1} \mathrm{~g}\right.$ of soil). The soil was analysed using chemical methods: soil $\mathrm{pH}$ was determined in a 1:2.5 soil $1 \mathrm{M} \mathrm{KCl}$ suspension after a half-hour equilibration period; hydrolytic acidity by $\mathrm{Ca}$ acetate extraction using Kappen's method; the sum of exchangeable basic cations by Kappen's method; humus content by Kotzmann's method; total nitrogen by Kjeldahl, and available $\mathrm{P}_{2} \mathrm{O}_{5}$ and $\mathrm{K}_{2} \mathrm{O}$ levels by the Egner-Riehm Al method.

\section{Statistical analysis}

Experimental data were analysed by descriptive and analytical statistics using the GenStat (2013) for $\mathrm{PC} / \mathrm{Windows} 7$, and significance of differences between means were determined according to Tukey test $(\mathrm{P}=$ 0.05 ) which represents the standard statistics for the experiment. Recorded data are presented as mean values with computed standard deviation $(\mathrm{Sd})$. The Pearson's correlation coefficient was obtained were tested at the $5 \%$ and $1 \%$ levels of significance. 


\section{Environmental variables}

The area of Kraljevo is located in the Čačak-Kraljevo valley that belongs to the Western Morava river region, in Serbia. It is surrounded by a large number of mountain ranges and their hills through which the wide river valleys of the West Morava, the lower Ibar and the lower Gruža intersect. It is located at $20^{\circ} 40^{\prime} 60^{\prime \prime} \mathrm{E}$ longitude and $43^{\circ} 43^{\prime} 00^{\prime \prime} \mathrm{N}$ latitude. The soil of the studied area is in a zone of temperate continental climate, with uneven distribution of precipitation by months. Based on the data of meteorological stations in Kraljevo, in the years in which the researches were carried out, differed from the long-term average characteristic of the area. The average air temperature was higher than the annual average by $0.58^{\circ} \mathrm{C}$ in 2015 , by $1.0^{\circ} \mathrm{C}$ in 2016 and by $1.46^{\circ} \mathrm{C}$ in 2017 (Table 1 ).

The total amounts of rainfall were above the perennial average in the surveyed growing seasons (2015, 2016, 2017), with a rather uneven monthly distribution. Weather conditions in the growing period in 2016 were marked by high rainfall during May, while rainfall in April was significantly lower. Variable and moderately warm weather, with less precipitation than average, marked June 2016 and 2017 (Table 1).

Table 1. Precipitation sum and average monthly temperature in Kraljevo, Serbia

\begin{tabular}{|c|c|c|c|c|c|c|}
\hline \multirow{2}{*}{ Year } & \multicolumn{5}{|c|}{ Months } & \multirow{2}{*}{ Average } \\
\hline & III & IV & $\mathrm{V}$ & VI & VI & \\
\hline \multicolumn{7}{|c|}{ Mean monthly air temperature $\left({ }^{\circ} \mathrm{C}\right)$} \\
\hline 2015 & 6.3 & 11.6 & 17.6 & 19.7 & 24.6 & 15.96 \\
\hline 2016 & 7.8 & 14.1 & 15.5 & 21.3 & 23.2 & 16.38 \\
\hline 2017 & 10.3 & 11.3 & 16.2 & 22.4 & 24.0 & 16.84 \\
\hline 30-year average & 6.5 & 11.7 & 16.2 & 19.1 & 23.4 & 15.38 \\
\hline \multicolumn{7}{|c|}{ The amount of rainfall $(\mathrm{mm})$} \\
\hline 2015 & 163.5 & 64.2 & 91.2 & 89.7 & 9.3 & 417.9 \\
\hline 2016 & 157.9 & 39.9 & 135.9 & 48.6 & 29.1 & 411.4 \\
\hline 2017 & 57.7 & 82.1 & 99.9 & 56.2 & 35.2 & 331.1 \\
\hline 30-year average & 44.7 & 65.1 & 74.9 & 86.5 & 38.8 & 310.0 \\
\hline
\end{tabular}

Temperature variations on average were higher in the third compared to the first and second seasons. During the run of the experiment (2015-2017), the differences between the mean precipitation values and the perennial average in the first and second years of the study were the highest in March and May.

\section{Results}

\section{Grain yield}

The average GY of spring oats for the whole trial over the three-year study period was $2.677 \mathrm{t} \mathrm{ha}^{-1}$, Table 2. A significantly higher GY compared to the non-fertilizer variant was achieved on all fertilizer variants. On average for all fertilizer variants, the highest GY $\left(3.802 \mathrm{t} \mathrm{ha}^{-1}\right)$ was obtained on the fertilizer variant $\mathrm{T} 5$ with $120 \mathrm{~kg} \mathrm{~N} \mathrm{ha}^{-1}, 80 \mathrm{~kg} \mathrm{P}_{2} \mathrm{O}_{5} \mathrm{ha}^{-1}, 80 \mathrm{~kg} \mathrm{~K}_{2} \mathrm{O} \mathrm{ha}^{-1}, 30 \mathrm{t} \mathrm{ha}^{-1}$ of manure and $5 \mathrm{t} \mathrm{ha} \mathrm{a}^{-1}$ of lime.

The combined application of lime, manure and mineral NPK fertilizers resulted in a significant increase in the yield of oats compared to the other fertilizer variants tested. Based on the analysis of variance, it can be concluded that the influence of growing season on GY was significant $(F=3.426)$, while the influence of different fertilization treatments on GY was highly significant $\left(F=51.477^{\prime \prime}\right)$.

The highest average GY in the first year of testing was recorded for the fertilizer variant T5 (3.718 $\left.\mathrm{t} \mathrm{ha}^{-1}\right)$ and the lowest for control $\left(1.085 \mathrm{tha}^{-1}\right)$ in Table 2. Based on the analysis of variance, it can be concluded that the growing season on GY was significant $\left(F=6.475^{\circ}\right)$, while the influence of different fertilization treatments on GY was highly significant $\left(F=24.454^{*}\right)$. 
In the second year of testing, the highest GY of all fertilizer variants was achieved, also in this year, with the fertilizer variant T5 with $120 \mathrm{~kg} \mathrm{~N} \mathrm{ha}^{-1}, 80 \mathrm{~kg} \mathrm{P}_{2} \mathrm{O}_{5} \mathrm{ha}^{-1}, 80 \mathrm{~kg} \mathrm{~K}_{2} \mathrm{O} \mathrm{ha}^{-1}, 30 \mathrm{tha}^{-1}$ of manure and $5 \mathrm{tha}^{-1}$ of lime (4.454 $\mathrm{t} \mathrm{ha}^{-1}$ ). In 2016, GY was highly significant varied across treatments (Table 2).

In the second year of testing, the highest $\mathrm{GY}$ of all fertilizer variants was achieved, also in this year, with the fertilizer variant T5 with $120 \mathrm{~kg} \mathrm{~N} \mathrm{ha}^{-1}, 80 \mathrm{~kg} \mathrm{P}_{2} \mathrm{O}_{5} \mathrm{ha}^{-1}, 80 \mathrm{~kg} \mathrm{~K}_{2} \mathrm{O} \mathrm{ha}^{-1}, 30 \mathrm{t} \mathrm{ha}^{-1}$ of manure and $5 \mathrm{tha} \mathrm{h}^{-1}$ of lime (4.454 $\left.\mathrm{t} \mathrm{ha}^{-1}\right)$. In 2016, GY was highly significant varied across treatments (Table 2).

Average GY of spring oats for all fertilizer variants in 2016 was $3.082 \mathrm{t} \mathrm{ha}^{-1}$ and was close to the average GY in the Republic of Serbia $\left(2.95 \mathrm{t} \mathrm{ha}^{-1}\right)$.

Table 2. Grain yield of spring oats in Kraljevo in Western Serbia

\begin{tabular}{|c|c|c|c|c|c|c|c|c|}
\hline \multirow{3}{*}{$\begin{array}{c}\text { Fertilization } \\
\text { Treatments }\end{array}$} & \multicolumn{6}{|c|}{ Years } & \multirow{2}{*}{\multicolumn{2}{|c|}{ Average }} \\
\hline & \multicolumn{2}{|c|}{2015} & \multicolumn{2}{|c|}{2016} & \multicolumn{2}{|c|}{2017} & & \\
\hline & $\bar{x}$ & $\mathrm{Sd}$ & $\bar{x}$ & $\mathrm{Sd}$ & $\bar{x}$ & $\mathrm{Sd}$ & $\bar{x}$ & $\mathrm{Sd}$ \\
\hline $\mathrm{T} 1$ & $1.085^{\mathrm{c}}$ & 0.441 & $1.363^{\mathrm{c}}$ & 0.383 & $0.910^{c}$ & 0.204 & $1.119^{\mathrm{d}}$ & 0.383 \\
\hline T2 & $2.477^{b}$ & 0.180 & $2.908^{b}$ & 0.258 & $2.161^{b}$ & 0.355 & $2.515^{c}$ & 0.406 \\
\hline T3 & $2.631^{\mathrm{b}}$ & 0.466 & $2.989^{\mathrm{b}}$ & 0.555 & $2.574^{\mathrm{ab}}$ & 0.838 & $2.731^{b c}$ & 0.622 \\
\hline $\mathrm{T} 4$ & $3.118^{\mathrm{ab}}$ & 0.576 & $3.694^{\mathrm{ab}}$ & 0.345 & $2.835^{\mathrm{ab}}$ & 0.433 & $3.216^{\mathrm{b}}$ & 0.565 \\
\hline T5 & $3.718^{\mathrm{a}}$ & 0.450 & $4.454^{\mathrm{a}}$ & 0.531 & $3.235^{\mathrm{a}}$ & 0.354 & $3.802^{\mathrm{a}}$ & 0.666 \\
\hline $\mathrm{F}$ & $24.454^{* *}$ & & $35.561^{* *}$ & & $16.773^{* *}$ & & $51.477^{* *}$ & \\
\hline $\mathrm{P}$ & $<0.001$ & & $<0.001$ & & $<0.001$ & & $<0.001$ & \\
\hline \multicolumn{9}{|l|}{ Years } \\
\hline Average & $2.606^{\mathrm{AB}}$ & 0.980 & $3.082^{\mathrm{A}}$ & 1.117 & $2.343^{\mathrm{B}}$ & 0.927 & 2.677 & 1.044 \\
\hline $\mathrm{F}$ & $6.475^{\circ}$ & & 0.951 & & 2.559 & & $3.426^{*}$ & \\
\hline $\mathrm{P}$ & 0.014 & & 0.334 & & 0.116 & & 0.038 & \\
\hline
\end{tabular}

${ }^{1}$ T1-control, T2- $\mathrm{N}_{80}$, T3- $\mathrm{N}_{120} \mathrm{P}_{80} \mathrm{~K}_{80}$, T4- $\mathrm{N}_{120} \mathrm{P}_{80} \mathrm{~K}_{80}+5$ t ha $^{-1}$ lime and T5- $\mathrm{N}_{120} \mathrm{P}_{80} \mathrm{~K}_{80}+30$ t ha ${ }^{-1}$ manure +5 tha ${ }^{-1}$ lime

${ }^{2}$ Within years and treatments, the values in each column followed by a different letter are significantly different; ", " significant at 0.05 and 0.01

The average GY of all fertilizer variants in 2017 was $2.343 \mathrm{tha}^{-1}$, which is $3.9 \%$ less than the average in the Republic of Serbia (Figure 1B). The highest average GY in the third year was the fertilization variant T5 $\left(3.235 \mathrm{tha}^{-1}\right)$, and the slightly lower GY the variant T4 $\left(2.835 \mathrm{t} \mathrm{ha}^{-1}\right)$. In 2017, GY was highly significant varied across treatments $\left(\mathrm{F}=16.773^{*}\right)$ in Table 2 .

\section{0 grain weight}

The TGW, average for all fertilizer variants, was the highest in 2016 (29.50 g), slightly lower in 2015 $(28.81 \mathrm{~g})$ and the lowest in $2017(27.32 \mathrm{~g})$ in Table 3.

The fertilizer variants tested differed in terms of TGW. On average for all years, the highest TGW had the fertilizer variant T5 $(29.71 \mathrm{~g})$ and the lowest $27.88 \mathrm{~g}$ variant T2 $\left(80 \mathrm{~kg} \mathrm{ha}^{-1} \mathrm{~N}\right)$. Growing period in $2017 \mathrm{at}$ the time of grain loading was marked by drought and high temperatures, which reduced the TGW.

The 1000 grain weight in the studied spring oats showed highly significant dependence on the year of study $\left(\mathrm{F}=10.488^{* \prime}\right)$ and very significant in the $2015\left(\mathrm{~F}=14.930^{*}\right)$ and $2016\left(\mathrm{~F}=8.690^{* \prime}\right)$. Different fertilizer treatments did not significantly affect in the TGW (Table 3).

\section{Hectolitre weight}

The HW, average for all fertilizer variants, was the highest in $2016\left(45.79 \mathrm{~kg} \mathrm{~h}^{-1}\right)$ compared to 2017 $\left(39.70 \mathrm{~kg} \mathrm{hl}^{-1}\right)$ in Table 4.

Regardless of the year, control (T1) and variant with combined application of NPK fertilizer with lime and manure (T5) had the highest HW. However, observed by years, there is considerable disagreement on their 
differences. Hectolitre weight of grain in oats showed high dependence from the growing seasons $(\mathrm{F}=$ $\left.121.499^{\prime \prime}\right)$ in Table 4.

Table 3. 1000 grain weight of spring oats in Kraljevo in Western Serbia

\begin{tabular}{|c|c|c|c|c|c|c|c|c|}
\hline \multirow{3}{*}{$\begin{array}{l}\text { Fertilization } \\
\text { Treatments }\end{array}$} & \multicolumn{6}{|c|}{ Years } & \multirow{2}{*}{\multicolumn{2}{|c|}{ Average }} \\
\hline & \multicolumn{2}{|c|}{2015} & \multicolumn{2}{|c|}{2016} & \multicolumn{2}{|c|}{2017} & & \\
\hline & $\bar{x}$ & $\mathrm{Sd}$ & $\bar{x}$ & $\mathrm{Sd}$ & $\bar{x}$ & $\mathrm{Sd}$ & $\bar{x}$ & $\mathrm{Sd}$ \\
\hline $\mathrm{T} 1$ & $28.98^{a}$ & 1.141 & $29.98^{a}$ & 0.432 & $26.30^{a}$ & 0.758 & $28.42^{\mathrm{a}}$ & 1.782 \\
\hline $\mathrm{T} 2$ & $28.60^{\mathrm{a}}$ & 0.696 & $28.94^{a}$ & 2.043 & $26.10^{a}$ & 1.907 & $27.88^{a}$ & 2.022 \\
\hline T3 & $28.84^{a}$ & 1.167 & $29.32^{\mathrm{a}}$ & 0.811 & $27.46^{\mathrm{a}}$ & 4.421 & $28.54^{\mathrm{a}}$ & 2.613 \\
\hline $\mathrm{T} 4$ & $28.22^{\mathrm{a}}$ & 0.672 & $28.42^{\mathrm{a}}$ & 2.075 & $27.82^{\mathrm{a}}$ & 1.402 & $28.15^{\mathrm{a}}$ & 1.410 \\
\hline T5 & $29.42^{\mathrm{a}}$ & 0.996 & $30.82^{\mathrm{a}}$ & 1.018 & $28.90^{\mathrm{a}}$ & 0.828 & $29.71^{a}$ & 1.216 \\
\hline$F$ & 1.081 & & 2.100 & & 1.253 & & 2.110 & \\
\hline $\mathrm{P}$ & 0.393 & & 0.118 & & 0.321 & & 0.089 & \\
\hline \multicolumn{9}{|l|}{ Years } \\
\hline Average & $28.81^{\mathrm{A}}$ & 0.965 & $29.50^{\mathrm{A}}$ & 1.566 & $27.32^{\mathrm{B}}$ & 2.346 & 28.54 & 1.929 \\
\hline $\mathrm{F}$ & $14.930^{* *}$ & & $8.690^{* *}$ & & 3.460 & & $10.488^{* *}$ & \\
\hline $\mathrm{P}$ & $<0.001$ & & 0.005 & & 0.069 & & $<0.001$ & \\
\hline
\end{tabular}

${ }^{1}$ T1-control, T2- $\mathrm{N}_{80}$, T3- $\mathrm{N}_{120} \mathrm{P}_{80} \mathrm{~K}_{80}$, T4- $\mathrm{N}_{120} \mathrm{P}_{80} \mathrm{~K}_{80}+5 \mathrm{t} \mathrm{ha}^{-1}$ lime and T5- $\mathrm{N}_{120} \mathrm{P}_{80} \mathrm{~K}_{80}+30 \mathrm{t}$ ha ${ }^{-1}$ manure $+5 \mathrm{t} \mathrm{ha}^{-1}$ lime

${ }^{2}$ Within years and treatments, the values in each column followed by a different letter are significantly different; ; ," significant at 0.05 and 0.01

Table 4. Hectoliter weight of spring oats in Kraljevo in Western Serbia

\begin{tabular}{|c|c|c|c|c|c|c|c|c|}
\hline \multirow{3}{*}{$\begin{array}{l}\text { Fertilization } \\
\text { Treatments }\end{array}$} & \multicolumn{6}{|c|}{ Years } & \multirow{2}{*}{\multicolumn{2}{|c|}{ Average }} \\
\hline & \multicolumn{2}{|c|}{2015} & \multicolumn{2}{|c|}{2016} & \multicolumn{2}{|c|}{2017} & & \\
\hline & $\bar{x}$ & $\mathrm{Sd}$ & $\bar{x}$ & $\mathrm{Sd}$ & $\bar{x}$ & $\mathrm{Sd}$ & $\bar{x}$ & $\mathrm{Sd}$ \\
\hline T1 & $44.80^{a}$ & 0.417 & $46.63^{a}$ & 0.769 & $38.95^{\mathrm{a}}$ & 0.864 & $43.46^{\mathrm{a}}$ & 3.454 \\
\hline $\mathrm{T} 2$ & $42.58^{\mathrm{a}}$ & 0.912 & $44.38^{\mathrm{a}}$ & 0.672 & $39.82^{a}$ & 1.278 & $42.26^{a}$ & 2.144 \\
\hline T3 & $42.90^{\mathrm{a}}$ & 2.659 & $46.37^{a}$ & 2.518 & $39.74^{a}$ & 0.576 & $43.00^{a}$ & 3.432 \\
\hline T4 & $43.20^{a}$ & 1.306 & $45.39^{a}$ & 1.520 & $39.50^{a}$ & 1.182 & $42.70^{a}$ & 2.807 \\
\hline $\mathrm{T} 5$ & $44.40^{\mathrm{a}}$ & 0.359 & $46.19^{a}$ & 0.939 & $40.50^{a}$ & 0.348 & $43.70^{a}$ & 2.524 \\
\hline $\mathrm{F}$ & 2.380 & & 1.980 & & 1.860 & & 0.587 & \\
\hline $\mathrm{P}$ & 0.086 & & 0.137 & & 0.156 & & 0.673 & \\
\hline \multicolumn{9}{|l|}{ Years } \\
\hline Average & $43.58^{\mathrm{B}}$ & 1.561 & $45.79^{\mathrm{A}}$ & 1.569 & $39.70^{\mathrm{C}}$ & 0.984 & 43.02 & 2.885 \\
\hline $\mathrm{F}$ & $270.431^{* *}$ & & $110.221^{* *}$ & & 25.070 & & $121.499^{*}$ & \\
\hline $\mathrm{P}$ & $<0.001$ & & $<0.001$ & & $<0.001$ & & $<0.001$ & \\
\hline
\end{tabular}

${ }^{1}$ T1-control, T2- $\mathrm{N}_{80}$, T3- $\mathrm{N}_{120} \mathrm{P}_{80} \mathrm{~K}_{80}$, T4- $\mathrm{N}_{120} \mathrm{P}_{80} \mathrm{~K}_{80}+5 \mathrm{t} \mathrm{ha}^{-1}$ lime and T5- $\mathrm{N}_{120} \mathrm{P}_{80} \mathrm{~K}_{80}+30 \mathrm{t} \mathrm{ha}^{-1}$ manure $+5 \mathrm{t} \mathrm{ha} \mathrm{a}^{-1}$ lime

${ }^{2}$ Within years and treatments, the values in each column followed by a different letter are significantly different; , " significant at 0.05 and 0.01

The highest HW in the first year of testing had control T1 $\left(44.80 \mathrm{~kg} \mathrm{hl}^{-1}\right.$ and the lowest variant T2 with $80 \mathrm{~kg} \mathrm{~N} \mathrm{ha}^{-1}\left(42.58 \mathrm{~kg} \mathrm{~h}^{-1}\right)$. In the second year of testing, T1 $\left(46.63 \mathrm{~kg} \mathrm{~h}^{-1}\right)$ had the highest HW. The highest $\mathrm{HW}$ in the third year had the fertilization variants T2 and T5 (39.82 kg hl${ }^{-1}$ and $40.50 \mathrm{~kg} \mathrm{hl}^{-1}$, respectively), and the slightly lower value variant T3 $\left(39.74 \mathrm{~kg} \mathrm{hl}^{-1}\right)$. Analysing the variance between the fertilizer treatments tested, no statistical significance was found for the HW, Table 4. 


\section{Plant height}

The highest value for PH of all fertilizer variants tested averaged significantly higher in 2016 (110.58 $\mathrm{cm})$, slightly lower in $2015(105.8 \mathrm{~cm})$ and the lowest in $2017(101.64 \mathrm{~cm})$. The average three-year value of PH was $106.01 \mathrm{~cm}$ and ranged from $82.267 \mathrm{~cm}$ in control to $116.37 \mathrm{~cm}$ in the fertilizer variant with NPK, manure and lime in Table 5. Very high influence of mineral nutrition on the $\mathrm{PH}$ was found $(\mathrm{P}<0.01)$ among the tested fertilizer variants. Based on the analysis of variance, it can be concluded that the growing season, i.e. years of research did not significantly affect the height of the $\mathrm{PH}(\mathrm{P}>0.05)$.

Table 5. Plant height of spring oats in Kraljevo in Western Serbia

\begin{tabular}{|c|c|c|c|c|c|c|c|c|}
\hline \multirow{2}{*}{ Fertilization } & \multicolumn{9}{|c|}{ Years } & \multicolumn{2}{c|}{ Average } \\
\cline { 2 - 9 } & \multicolumn{2}{|c|}{2015} & \multicolumn{2}{c|}{2016} & \multicolumn{2}{c|}{2017} & \multicolumn{2}{c|}{ Sd } \\
\hline Treatments & $\bar{x}$ & $\mathrm{Sd}$ & $\bar{x}$ & $\mathrm{Sd}$ & $\bar{x}$ & $\bar{x}$ & \multicolumn{2}{c|}{ Sd } \\
\hline T1 & $82.60^{\mathrm{b}}$ & 11.238 & $85.20^{\mathrm{b}}$ & 6.573 & $79.00^{\mathrm{b}}$ & 5.000 & $82.267^{\mathrm{c}}$ & 7.905 \\
\hline T2 & $106.00^{\mathrm{a}}$ & 10.075 & $111.00^{\mathrm{a}}$ & 8.775 & $101.80^{\mathrm{a}}$ & 10.756 & $106.27^{\mathrm{b}}$ & 9.960 \\
\hline T3 & $110.60^{\mathrm{a}}$ & 9.685 & $117.50^{\mathrm{a}}$ & 3.000 & $106.20^{\mathrm{a}}$ & 7.918 & $111.43^{\mathrm{ab}}$ & 8.394 \\
\hline T4 & $112.90^{\mathrm{a}}$ & 6.128 & $118.60^{\mathrm{a}}$ & 5.683 & $109.60^{\mathrm{a}}$ & 4.615 & $113.70^{\mathrm{ab}}$ & 6.391 \\
\hline T5 & $116.90^{\mathrm{a}}$ & 4.307 & $120.60^{\mathrm{a}}$ & 4.393 & $111.60^{\mathrm{a}}$ & 5.320 & $116.37^{\mathrm{a}}$ & 5.789 \\
\hline F & $12.161^{* *}$ & & $29.623^{* *}$ & & $17.192^{* *}$ & & $46.465^{* *}$ & \\
\hline P & $<0.001$ & & $<0.001$ & & $<0.001$ & & $<0.001$ & \\
\hline Years & & & & & & & & \\
\hline Average & $105.80^{\mathrm{A}}$ & 14.699 & $110.58^{\mathrm{A}}$ & 14.445 & $101.64^{\mathrm{A}}$ & 13.680 & 106.01 & 14.559 \\
\hline F & $5.048^{*}$ & & 1.073 & & 1.345 & & 2.453 & \\
\hline P & 0.029 & & 0.305 & & 0.252 & & 0.093 & \\
\hline
\end{tabular}

${ }^{1}$ T1-control, T2- $\mathrm{N}_{80}$, T3- $\mathrm{N}_{120} \mathrm{P}_{80} \mathrm{~K}_{80}$, T4- $\mathrm{N}_{120} \mathrm{P}_{80} \mathrm{~K}_{80}+5 \mathrm{t} \mathrm{ha}^{-1}$ lime and T5- $\mathrm{N}_{120} \mathrm{P}_{80} \mathrm{~K}_{80}+30 \mathrm{t}$ ha ${ }^{-1}$ manure $+5 \mathrm{tha}{ }^{-1}$ lime

${ }^{2}$ Within years and treatments, the values in each column followed by a different letter are significantly different; , ". significant at 0.05 and 0.01

In 2015 year, the highest $\mathrm{PH}$ was found in variants with treatment $\mathrm{T} 4(112.9 \mathrm{~cm})$ and variant $\mathrm{T} 5$ with NPK, manure and lime $(116.9 \mathrm{~cm})$. The assessment of significance of the obtained results shows highly significant differences between the $\mathrm{PH}$ and fertilizer variants $\left(\mathrm{F}=12.161^{\prime \prime}\right)$ and significant differences between the growing seasons on the $\mathrm{PH}\left(\mathrm{F}=5.048^{*}\right)$, Table 5 .

\section{Panicle length}

The panicle length is a quantitative trait that represents the carrier of the genital branches. The panicle length in the second year of study (2016) was the highest at $26.82 \mathrm{~cm}$, while the lowest value was found in the third year $(23.38 \mathrm{~cm})$. A significantly higher PL compared to the non-fertilizer variant was achieved on all fertilizer treatments.

In 2015, PL highly significant varied across treatments, was the highest at $26.40 \mathrm{~cm}$ in treatment $\mathrm{T} 5$ and the lowest the control T1 $(21.40 \mathrm{~cm})$. In the second year of study (2016) PL highly significant varied across treatments, was the highest at $29.70 \mathrm{~cm}$ in treatment T5 and the lowest the control $(22.20 \mathrm{~cm})$ in Table 6 .

The highest average 3-year PL had the T5 variant $(26.90 \mathrm{~cm})$ and the lowest the control $(21.50 \mathrm{~cm})$. The results of the analysis of variance show that the growing season, i.e., the study three-year, have a very significant influence on the PL $\left(\mathrm{F}=9.785^{*}\right)$.

The highly significance of the influence of mineral nutrition on the $\mathrm{PL}$ was determined $(\mathrm{P}<0.01)$. The highest PL in all three years of the study was found in the T5 fertilizer variant with NPK, manure and lime in Table 6. 
Table 6. Length of panicle of spring oats in Kraljevo in Western Serbia

\begin{tabular}{|c|c|c|c|c|c|c|c|c|}
\hline \multirow{3}{*}{$\begin{array}{l}\text { Fertilization } \\
\text { Treatments }\end{array}$} & \multicolumn{6}{|c|}{ Years } & \multirow{2}{*}{\multicolumn{2}{|c|}{ Average }} \\
\hline & \multicolumn{2}{|c|}{2015} & \multicolumn{2}{|c|}{2016} & \multicolumn{2}{|c|}{2017} & & \\
\hline & $\bar{x}$ & $\mathrm{Sd}$ & $\bar{x}$ & $\mathrm{Sd}$ & $\bar{x}$ & $\mathrm{Sd}$ & $\bar{x}$ & $\mathrm{Sd}$ \\
\hline $\mathrm{T} 1$ & $21.40^{\mathrm{b}}$ & 2.043 & $22.20^{\mathrm{b}}$ & 1.037 & $20.90^{\mathrm{a}}$ & 2.073 & $21.50^{\mathrm{b}}$ & 1.742 \\
\hline $\mathrm{T} 2$ & $24.60^{\mathrm{ab}}$ & 1.387 & $26.50^{a}$ & 2.398 & $23.20^{\mathrm{a}}$ & 1.037 & $24.77^{a}$ & 2.112 \\
\hline T3 & $25.20^{\mathrm{a}}$ & 2.280 & $27.20^{a}$ & 2.280 & $24.40^{\mathrm{a}}$ & 2.510 & $25.60^{\mathrm{a}}$ & 2.501 \\
\hline T4 & $25.80^{\mathrm{a}}$ & 2.049 & $28.50^{\mathrm{a}}$ & 3.041 & $23.80^{\mathrm{a}}$ & 2.775 & $26.03^{a}$ & 3.165 \\
\hline T5 & $26.40^{\mathrm{a}}$ & 1.817 & $29.70^{a}$ & 1.718 & $24.60^{\mathrm{a}}$ & 2.302 & $26.90^{a}$ & 2.842 \\
\hline$F$ & $5.069^{* *}$ & & $8.439^{* *}$ & & 2.251 & & $10.205^{* *}$ & \\
\hline $\mathrm{P}$ & 0.005 & & $<0.001$ & & 0.099 & & $<0.001$ & \\
\hline \multicolumn{9}{|l|}{ Years } \\
\hline Average & $24.68^{\mathrm{B}}$ & 2.512 & $26.82^{\mathrm{A}}$ & 3.294 & $23.38^{\mathrm{B}}$ & 2.442 & 24.96 & 3.088 \\
\hline $\mathrm{F}$ & $17.593^{* *}$ & & 3.442 & & $6.671^{*}$ & & $9.785^{* *}$ & \\
\hline $\mathrm{P}$ & $<0.001$ & & 0.070 & & 0.013 & & $<0.001$ & \\
\hline
\end{tabular}

T1-control, T2- $\mathrm{N}_{80}$, T3- $\mathrm{N}_{120} \mathrm{P}_{80} \mathrm{~K}_{80}$, T4- $\mathrm{N}_{120} \mathrm{P}_{80} \mathrm{~K}_{80}+5 \mathrm{t} \mathrm{ha}^{-1}$ lime and T5- $\mathrm{N}_{120} \mathrm{P}_{80} \mathrm{~K}_{80}+30 \mathrm{t} \mathrm{ha}^{-1}$ manure $+5 \mathrm{t} \mathrm{ha}^{-1}$ lime

${ }^{2}$ Within years and treatments, the values in each column followed by a different letter are significantly different; , , significant at 0.05 and 0.01

\section{Number of grains per panicle}

All fertilizer variants tested formed a significantly higher number of grains per panicle 115 in 2016 than 100 in 2017. The highest NGP in all three years of research, were recorded in following variant T5 fertilized with NPK, manure and lime and variant T4 fertilized with NPK. A significantly higher NGP compared to the non-fertilizer variant was achieved on all fertilizer variants in 2016 year $\left(\mathrm{F}=9.765^{* *}\right)$ and 2017 year $(\mathrm{F}=$ $\left.17.717^{* *}\right)$ and significant in the 2015 year $\left(F=2.919^{*}\right)$ in Table 7.

Table 7. Number of grains (panicle) of spring oats in Kraljevo in Western Serbia

\begin{tabular}{|c|c|c|c|c|c|c|c|c|}
\hline \multirow{3}{*}{$\begin{array}{l}\text { Fertilization } \\
\text { Treatments }\end{array}$} & \multicolumn{6}{|c|}{ Years } & \multirow{2}{*}{\multicolumn{2}{|c|}{ Average }} \\
\hline & \multicolumn{2}{|c|}{2015} & \multicolumn{2}{|c|}{2016} & \multicolumn{2}{|c|}{2017} & & \\
\hline & $\bar{x}$ & $\mathrm{Sd}$ & $\bar{x}$ & $\mathrm{Sd}$ & $\bar{x}$ & $\mathrm{Sd}$ & $\bar{x}$ & $\mathrm{Sd}$ \\
\hline $\mathrm{T} 1$ & $78^{\mathrm{a}}$ & 25.541 & $79^{c}$ & 20.359 & $75^{c}$ & 16.471 & $77^{\mathrm{c}}$ & 19.613 \\
\hline $\mathrm{T} 2$ & $98^{\mathrm{a}}$ & 9.209 & $102^{\mathrm{bc}}$ & 13.240 & $93^{\mathrm{b}}$ & 3.114 & $98^{\mathrm{b}}$ & 9.603 \\
\hline T3 & $113^{a}$ & 42.312 & $122^{\mathrm{ab}}$ & 25.324 & $108^{\mathrm{ab}}$ & 7.616 & $115^{\mathrm{ab}}$ & 27.370 \\
\hline $\mathrm{T} 4$ & $117^{\mathrm{a}}$ & 5.891 & $135^{a}$ & 12.462 & $111^{\mathrm{a}}$ & 5.128 & $121^{\mathrm{a}}$ & 13.184 \\
\hline T5 & $119^{a}$ & 5.167 & $135^{a}$ & 10.099 & $114^{a}$ & 1.923 & $123^{a}$ & 11.095 \\
\hline $\mathrm{F}$ & $2.919^{*}$ & & $9.765^{* *}$ & & $17.717^{* *}$ & & $18.115^{* *}$ & \\
\hline $\mathrm{P}$ & 0.047 & & $<0.001$ & & $<0.001$ & & $<0.001$ & \\
\hline \multicolumn{9}{|l|}{ Years } \\
\hline Average & $105^{\mathrm{A}}$ & 26.166 & $115^{\mathrm{A}}$ & 27.066 & $100^{\mathrm{A}}$ & 16.716 & 107 & 24.227 \\
\hline $\mathrm{F}$ & $5.123^{*}$ & & 0.511 & & 1.749 & & 2.403 & \\
\hline $\mathrm{P}$ & 0.028 & & 0.478 & & 0.192 & & 0.098 & \\
\hline
\end{tabular}

${ }^{1}$ T1-control, T2- $\mathrm{N}_{80}$, T3- $\mathrm{N}_{120} \mathrm{P}_{80} \mathrm{~K}_{80}$, T4- $\mathrm{N}_{120} \mathrm{P}_{80} \mathrm{~K}_{80}+5 \mathrm{tha}^{-1}$ lime and T5- $\mathrm{N}_{120} \mathrm{P}_{80} \mathrm{~K}_{80}+30 \mathrm{t} \mathrm{ha}{ }^{-1}$ manure $+5 \mathrm{t} \mathrm{ha}^{-1}$ lime

${ }^{2}$ Within years and treatments, the values in each column followed by a different letter are significantly different; , " significant at 0.05 and 0.01

The highest three-year average NGP was found in variant T5 (123) and slightly lower in variant T4 (121), while the lowest was in the control (77) in Table 7. 
A very high influence in the three-year of mineral nutrition on NGP was found among the tested fertilizer treatments $(\mathrm{P}<0.01)$. Based on the analysis of variance, it can be concluded that the growing season, i.e. the year of the study, did not significantly affect the NGP $(\mathrm{P}>0.05)$.

\section{Protein content of oat grain}

The fertilizer variants tested varied significantly higher in the PC of the grain in Table 8. The highest PC in the study in 2015 year had T1 treatment (12.710\%) and the lowest T5 treatment (9.904\%). A significantly higher PC compared to all fertilizer treatments was achieved in the treatment $\mathrm{T} 1$.

Table 8. Protein content of spring oats in Kraljevo, Serbia

\begin{tabular}{|c|c|c|c|c|c|c|c|c|}
\hline \multirow{3}{*}{$\begin{array}{c}\text { Fertilization } \\
\text { Treatments }\end{array}$} & \multicolumn{6}{|c|}{ Years } & \multirow{2}{*}{\multicolumn{2}{|c|}{ Average }} \\
\hline & \multicolumn{2}{|c|}{2015} & \multicolumn{2}{|c|}{2016} & \multicolumn{2}{|c|}{2017} & & \\
\hline & $\bar{x}$ & $\mathrm{Sd}$ & $\bar{x}$ & $\mathrm{Sd}$ & $\bar{x}$ & $\mathrm{Sd}$ & $\bar{x}$ & $\mathrm{Sd}$ \\
\hline $\mathrm{T} 1$ & $12.710^{\mathrm{a}}$ & 0.379 & $12.850^{\mathrm{a}}$ & 0.364 & $10.848^{\mathrm{a}}$ & 0.221 & $12.136^{a}$ & 0.992 \\
\hline T2 & $12.036^{\mathrm{a}}$ & 0.331 & $12.158^{\mathrm{a}}$ & 0.897 & $10.634^{\mathrm{ab}}$ & 0.335 & $11.609^{a}$ & 0.898 \\
\hline T3 & $10.786^{\mathrm{b}}$ & 0.705 & $10.984^{\mathrm{b}}$ & 0.380 & $10.140^{\mathrm{ab}}$ & 0.342 & $10.637^{b}$ & 0.597 \\
\hline T4 & $10.204^{\mathrm{b}}$ & 0.597 & $10.562^{b}$ & 0.227 & $9.834^{\mathrm{ab}}$ & 0.946 & $10.200^{\mathrm{b}}$ & 0.683 \\
\hline T5 & $9.904^{b}$ & 0.405 & $10.362^{b}$ & 0.658 & $9.634^{b}$ & 0.760 & $9.967^{b}$ & 0.657 \\
\hline $\mathrm{F}$ & $28.480^{* *}$ & & $18.470^{* *}$ & & $3.802^{*}$ & & $21.304^{* *}$ & \\
\hline $\mathrm{P}$ & $<0.001$ & & $<0.001$ & & 0.019 & & $<0.001$ & \\
\hline \multicolumn{9}{|l|}{ Years } \\
\hline Average & $11.128^{\mathrm{A}}$ & 1.191 & $11.383^{\mathrm{A}}$ & 1.107 & $10.218^{\mathrm{B}}$ & 0.717 & 10.910 & 1.130 \\
\hline $\mathrm{F}$ & $19.521^{* *}$ & & $10.710^{* *}$ & & 0.616 & & $8.909^{* *}$ & \\
\hline $\mathrm{P}$ & $<0.001$ & & 0.002 & & 0.436 & & $<0.001$ & \\
\hline
\end{tabular}

${ }^{1}$ T1-control, T2- $\mathrm{N}_{80}$, T3- $\mathrm{N}_{120} \mathrm{P}_{80} \mathrm{~K}_{80}$, T4- $\mathrm{N}_{120} \mathrm{P}_{80} \mathrm{~K}_{80}+5 \mathrm{tha}^{-1}$ lime and T5- $\mathrm{N}_{120} \mathrm{P}_{80} \mathrm{~K}_{80}+30 \mathrm{t}$ ha ${ }^{-1}$ manure $+5 \mathrm{tha}{ }^{-1}$ lime

${ }^{2}$ Within years and treatments, the values in each column followed by a different letter are significantly different; , ' significant at 0.05 and 0.01

In the second and third year of study, the highest PC was achieved by T1 treatment $(12.850 \%$ and 10.848). The highest average PC of spring oat grains of all fertilizer variants was found in 2016 and amounted to $11.383 \%$, while the lowest content was found in 2017 (10.218\%) in Table 11. Based on the analysis of variance, it can be concluded that the different fertilization treatments highly influences the PC in 2015 (F = $\left.28.480^{\circ}\right)$ and $2016\left(\mathrm{~F}=18.470^{*}\right)$ and significant in $2017\left(\mathrm{~F}=3.802^{*}\right)$. On average for all fertilizer variants in three-years study, the highest PC (12.136\%) was obtained on the fertilizer variant T1. Based on the analysis of variance in three-year study, it can be concluded that the influence of growing seasons on PC was highly significant $\left(\mathrm{F}=21.304^{* *}\right)$. Different fertilization variants in study, highly influenced the $\mathrm{PC}$ of the grain $(\mathrm{F}=$ $8.909 ")$, Table 8.

\section{Correlation analysis of the studied oat traits}

Correlation coefficients based on all traits tested during 2014,2015, and 2016 had positive and negative values in Table 9.

Positive correlation coefficients, during 2015 (Table 9), were found between GY with the PH $\left(\mathrm{r}=0.827^{\prime \prime}\right)$, PL $\left(\mathrm{r}=0.754^{\prime \prime}\right)$ and NGP $\left(\mathrm{r}=0.615^{\circ}\right)$, between PH with PL $\left(\mathrm{r}=0.736^{\prime \prime}\right)$ and the NGP $\left(\mathrm{r}=0.709^{\prime \prime}\right)$ and between the PL and NGP $\left(\mathrm{r}=0.719^{\prime \prime}\right)$.

Highly significant negative dependencies were found between PC with GY $\left(\mathrm{r}=-0.766^{*}\right)$ and PH $(\mathrm{r}=-$ $\left.0.677^{\prime \prime}\right)$ and significant were found between PC with PL $\left(\mathrm{r}=-0.496^{\circ}\right)$ and NGP $\left(\mathrm{r}=-0.495^{\circ}\right)$.

Highly significant and positive correlation coefficients, during 2016 in Table 9 , were found between GY with PH $\left(\mathrm{r}=0.805^{*}\right)$, PL $\left(\mathrm{r}=0.811^{* *}\right)$ and NGP $\left(\mathrm{r}=0.719^{* \prime}\right)$, between PH with PL $\left(\mathrm{r}=0.743^{* \prime}\right)$ and NGP 
$\left(\mathrm{r}=0.771^{\prime \prime}\right)$ and between PL and NGP $\left(\mathrm{r}=0.552^{\prime \prime}\right)$. Highly significant and negative dependencies were found between PC and PH ( $\left.r=-0.807^{\prime \prime}\right)$, PL $\left(r=-0.624^{\prime \prime}\right)$ and NGP $\left(r=-0.761^{\prime \prime}\right)$ and significant with GY $\left(r=-0.773^{\circ}\right)$.

During 2017, highly significant positive correlation coefficients were found between GY with PH $\left(\mathrm{r}=0.806^{\prime \prime}\right)$ and NGP $\left(\mathrm{r}=0.734^{\prime \prime}\right)$. A high and positive dependence was found between $\mathrm{PH}$ and NBP $\left(\mathrm{r}=0.802^{\prime \prime}\right)$ and between PL and NGP $\left(\mathrm{r}=0.608^{*}\right)$.

Significant and positive dependence was determined between GY and PL $\left(r=0.430^{*}\right)$, then between TGW and NGP $\left(r=0.403^{\circ}\right)$, between HW with PH $\left(r=0.492^{\circ}\right)$ and NGP $\left(r=0.406^{*}\right)$ as well as between PH and PL $\left(r=0.427^{\circ}\right)$. Negative dependencies were found between PC and GY ( $\left.r=-0.766^{*}\right)$, PH $\left(r=-0.677^{*}\right)$, PL $\left(\mathrm{r}=-0.496^{\circ}\right)$ and NGP $\left(\mathrm{r}=-0.495^{\circ}\right)$ in Table 9.

Table 9. Correlations between the traits analysed in the study period

\begin{tabular}{|c|c|c|c|c|c|c|c|}
\hline Traits & GY & TGW & HW & $\mathrm{PH}$ & PL & NGP & PC \\
\hline \multicolumn{8}{|c|}{2015} \\
\hline GY & 1.00 & 0.153 & -0.236 & $0.827^{* *}$ & $0.754^{* *}$ & $0.615^{* *}$ & $-0.766^{* *}$ \\
\hline TGW & & 1.00 & -0.192 & 0.045 & -0.075 & 0.104 & 0.016 \\
\hline HW & & & 1.00 & -0.312 & -0.175 & -0.150 & 0.066 \\
\hline $\mathrm{PH}$ & & & & 1.00 & $0.736^{*}$ & $0.709^{* *}$ & $-0.677^{* *}$ \\
\hline LP & & & & & 1.00 & $0.719^{* *}$ & $-0.496^{*}$ \\
\hline NGP & & & & & & 1.00 & $-0.495^{*}$ \\
\hline PC & & & & & & & 1.00 \\
\hline \multicolumn{8}{|c|}{2016} \\
\hline GY & 1.00 & -0.041 & -0.206 & $0.805^{*}$ & $0.811^{* *}$ & $0.719^{* *}$ & $-0.773^{*}$ \\
\hline TGW & & 1.00 & 0.121 & -0.109 & 0.038 & -0.114 & 0.021 \\
\hline HW & & & 1.00 & -0.213 & -0.312 & 0.193 & 0.001 \\
\hline $\mathrm{PH}$ & & & & 1.00 & $0.743^{* *}$ & $0.771^{* *}$ & $-0.807^{* *}$ \\
\hline LP & & & & & 1.00 & $0.552^{* *}$ & $-0.624^{* *}$ \\
\hline NGP & & & & & & 1.00 & $-0.761^{* *}$ \\
\hline $\mathrm{PC}$ & & & & & & & 1.00 \\
\hline \multicolumn{8}{|c|}{2017} \\
\hline GY & 1.00 & 0.169 & 0.269 & $0.806^{*}$ & $0.430^{*}$ & $0.734^{* *}$ & $-0.557^{* *}$ \\
\hline TGW & & 1.00 & 0.291 & 0.348 & 0.238 & $0.403^{*}$ & -0.317 \\
\hline HW & & & 1.00 & $0.492^{*}$ & 0.306 & $0.406^{*}$ & $-0.438^{*}$ \\
\hline $\mathrm{PH}$ & & & & 1.00 & $0.427^{*}$ & $0.802^{* *}$ & $-0.399^{*}$ \\
\hline LP & & & & & 1.00 & $0.608^{* *}$ & -0.374 \\
\hline NGP & & & & & & 1.00 & $-0.500^{*}$ \\
\hline $\mathrm{PC}$ & & & & & & & 1.00 \\
\hline \multicolumn{8}{|c|}{$\frac{1}{2015-2017}$} \\
\hline GY & 1.00 & 0.201 & 0.194 & $0.823^{* *}$ & $0.721^{* *}$ & $0.701^{* *}$ & $-0.494^{* *}$ \\
\hline TGW & & 1.00 & $0.456^{*}$ & 0.224 & $0.281^{*}$ & 0.202 & 0.139 \\
\hline HW & & & 1.00 & 0.176 & $0.331^{* *}$ & $0.245^{*}$ & $0.368^{* *}$ \\
\hline $\mathrm{PH}$ & & & & 1.00 & $0.670^{* *}$ & $0.759^{* *}$ & $-0.459^{* *}$ \\
\hline LP & & & & & 1.00 & $0.641^{* *}$ & -0.225 \\
\hline NGP & & & & & & 1.00 & $-0.428^{* *}$ \\
\hline PC & & & & & & & 1.00 \\
\hline
\end{tabular}

${ }^{1}$ GY-Grain yield $\left(\mathrm{t} \mathrm{ha}^{-1}\right)$, TGW-1000 grain weight $(\mathrm{g})$, HW-Hectolitre weight $\left(\mathrm{kg} \mathrm{hl}^{-1}\right)$, PH-Plant height $(\mathrm{cm})$, PLPanicle length (cm), NGP-Number of grains (panicle), PC-Protein content (\%);

${ }^{2}$ Within years and treatments, the values in each column followed by a different letter are significantly different; ;," significant at 0.05 and 0.01 ; 
Over a three-year study period (2015-2017), highly significant positive correlation coefficients were found between GY with the PH, PL and NGP, then between the HW with the TGW, PL and PC and between the PH with the PL and NGP in Table 9.

The correlation coefficients in different fertilizer variants based on all the traits tested had positive and negative values in Table 10.

Table 10. Correlation coefficients for the traits analysed across treatments

\begin{tabular}{|c|c|c|c|c|c|c|c|}
\hline Traits & GY & TGW & HW & $\mathrm{PH}$ & PL & NGP & PC \\
\hline \multicolumn{8}{|c|}{ T1-control } \\
\hline GY & 1.00 & 0.479 & 0.442 & 0.505 & 0.214 & 0.240 & -0.464 \\
\hline TGW & & 1.00 & $0.878^{* *}$ & 0.219 & 0.164 & -0.020 & $0.852^{* *}$ \\
\hline HW & & & 1.00 & 0.328 & 0.274 & 0.090 & $0.914^{* *}$ \\
\hline $\mathrm{PH}$ & & & & 1.00 & $0.563^{\circ}$ & $0.681^{* *}$ & 0.204 \\
\hline LP & & & & & 1.00 & $0.574^{*}$ & 0.143 \\
\hline NGP & & & & & & 1.00 & 0.021 \\
\hline PC & & & & & & & 1.00 \\
\hline \multicolumn{8}{|c|}{ T2-N } \\
\hline GY & 1.00 & 0.188 & $0.605^{\circ}$ & 0.442 & 0.418 & 0.506 & -0.461 \\
\hline TGW & & 1.00 & $0.653^{* \prime}$ & 0.223 & 0.335 & 0.020 & $0.552^{*}$ \\
\hline HW & & & 1.00 & 0.405 & $0.542^{\circ}$ & 0.308 & $0.676^{*}$ \\
\hline $\mathrm{PH}$ & & & & 1.00 & 0.324 & 0.506 & 0.014 \\
\hline LP & & & & & 1.00 & 0.315 & $0.648^{* *}$ \\
\hline NGP & & & & & & 1.00 & -0.083 \\
\hline PC & & & & & & & 1.00 \\
\hline \multicolumn{8}{|c|}{ T3-NPK } \\
\hline GY & 1.00 & -0.024 & -0.031 & $0.544^{\circ}$ & 0.371 & 0.168 & -0.210 \\
\hline TGW & & 1.00 & 0.243 & 0.175 & 0.180 & 0.285 & 0.014 \\
\hline HW & & & 1.00 & 0.422 & 0.257 & 0.307 & $0.545^{\circ}$ \\
\hline $\mathrm{PH}$ & & & & 1.00 & 0.189 & 0.453 & $0.566^{*}$ \\
\hline LP & & & & & 1.00 & 0.353 & 0.314 \\
\hline NGP & & & & & & 1.00 & 0.480 \\
\hline $\mathrm{PC}$ & & & & & & & 1.00 \\
\hline \multicolumn{8}{|c|}{ T4-NPK in combination with lime } \\
\hline GY & 1.00 & -0.037 & 0.481 & 0.393 & $0.718^{* *}$ & $0.529^{*}$ & -0.187 \\
\hline TGW & & 1.00 & -0.020 & $0.653^{* *}$ & 0.234 & -0.068 & 0.365 \\
\hline HW & & & 1.00 & 0.408 & $0.528^{+}$ & $0.753^{* *}$ & 0.323 \\
\hline $\mathrm{PH}$ & & & & 1.00 & $0.588^{*}$ & 0.408 & $0.667^{* \prime}$ \\
\hline LP & & & & & 1.00 & $0.518^{*}$ & 0.434 \\
\hline NGP & & & & & & 1.00 & 0.372 \\
\hline $\mathrm{PC}$ & & & & & & & 1.00 \\
\hline \multicolumn{8}{|c|}{ T5-NPK in combination with lime and manure } \\
\hline GY & 1.00 & 0.273 & $0.749^{* *}$ & 0.452 & $0.594^{*}$ & $0.588^{*}$ & -0.358 \\
\hline TGW & & 1.00 & $0.526^{*}$ & 0.463 & $0.613^{*}$ & $0.527^{*}$ & 0.335 \\
\hline HW & & & 1.00 & $0.592^{\circ}$ & $0.704^{* *}$ & $0.773^{* *}$ & 0.358 \\
\hline $\mathrm{PH}$ & & & & 1.00 & 0.415 & $0.526^{\circ}$ & 0.383 \\
\hline LP & & & & & 1.00 & 0.500 & 0.329 \\
\hline NGP & & & & & & 1.00 & 0.287 \\
\hline PC & & & & & & & 1.00 \\
\hline
\end{tabular}

${ }^{1}$ GY-Grain yield $\left(\mathrm{t} \mathrm{ha}^{-1}\right)$, TGW-1000 grain weight (g), HW-Hectolitre weight $\left(\mathrm{kg} \mathrm{h}^{-1}\right)$, PH-Plant height (cm), PLPanicle length (cm), NGP-Number of grains (panicle), PC-Protein content (\%);

${ }^{2}$ T1-control, T2- $\mathrm{N}_{80}$, T3- $\mathrm{N}_{120} \mathrm{P}_{80} \mathrm{~K}_{80}$, T4- $\mathrm{N}_{120} \mathrm{P}_{80} \mathrm{~K}_{80}+5 \mathrm{t} \mathrm{ha}^{-1}$ lime and T5- $\mathrm{N}_{120} \mathrm{P}_{80} \mathrm{~K}_{80}+30 \mathrm{tha}^{-1}$ manure $+5 \mathrm{tha}$ lime

${ }^{3}$ Within years and treatments, the values in each column followed by a different letter are significantly different; , " . significant at 0.05 and 0.01 ; 
Highly significant and positive correlation coefficients, in the variant without fertilization (T1), were found between TGW and HW ( $\left.\mathrm{r}=0.878^{*}\right)$, TGW and PC ( $\left.\mathrm{r}=0.852^{*}\right), \mathrm{HW}$ and PC $\left(\mathrm{r}=0.914^{*}\right)$ and between the PH and NGP $\left(\mathrm{r}=0.681^{*}\right)$. Significant and positive dependencies were found between PH and PL $\left(\mathrm{r}=0.563^{\circ}\right)$ and between PL and NGP $\left(\mathrm{r}=0.574^{*}\right)$ in Table 10.

In the nitrogen-only fertilization variant (T2), highly significant positive correlation coefficients were found between TGW and HW ( $\left.r=0.653^{\circ *}\right), \mathrm{HW}$ and PC $\left(\mathrm{r}=0.676^{\circ}\right)$, and between PL and PC $\left(\mathrm{r}=0.648^{* \prime}\right)$. Significant and positive dependence was found between TGW and PC $\left(\mathrm{r}=0.552^{\circ}\right)$ and between HW and PL $\left(\mathrm{r}=0.542^{*}\right)$ in Table 10.

Significant and positive correlation coefficients, in the fertilizer variant with NPK (T3), were found between GY and $\mathrm{PH}\left(\mathrm{r}=0.544^{\circ}\right)$ and between PC and HW $\left(\mathrm{r}=0.545^{\circ}\right)$ and $\mathrm{PC}$ and $\mathrm{PH}\left(\mathrm{r}=0.566^{\circ}\right)$. A negative correlation was found between the GY of oats and TGW ( $r=-0.024)$ and the GY and HW $(r=-0.031)$ in Table 10.

In the NPK and lime variant (T4), highly significant and positive correlation coefficients were found between GY and PL ( $\left.\mathrm{r}=0.718^{* *}\right)$, TGW and PH $\left(\mathrm{r}=0.653^{* \prime}\right)$, HW and NGP $\left(\mathrm{r}=0.753^{*}\right)$, as well as between PC and PH $\left(r=0.667^{\circ}\right)$. Significant and positive relationships were found between GY and NGP $\left(r=0.529^{\circ}\right)$, HW and PL $\left(\mathrm{r}=0.528^{\circ}\right), \mathrm{PH}$ and PL $\left(\mathrm{r}=0.588^{\circ}\right)$, and between the PL and NGP $\left(\mathrm{r}=0.518^{*}\right)$. A negative dependence was found between the GY of oats and TGW ( $r=-0.037)$, as well as between the TGW and HW ( $r=-0.020)$ in Table 10.

In the fertilizer variant with NPK, lime and manure (T5), highly significant positive correlation coefficients were found between HW with the GY $\left(\mathrm{r}=0.749^{*}\right)$, PL $\left(\mathrm{r}=0.704^{*}\right)$ and NGP $\left(\mathrm{r}=0.773^{* \prime}\right)$. Significant and positive dependence was found between GY with the PL $\left(r=0.594^{*}\right)$ and NGP $\left(r=0.588^{*}\right)$ and between TGW and HW ( $\left.\mathrm{r}=0.526^{*}\right)$, TGW and PL $\left(\mathrm{r}=0.613^{*}\right)$ and TGW and NGP $\left(\mathrm{r}=0.588^{*}\right)$. Also, a positive and significant dependence was found between the PH and HW $\left(r=0.592^{\circ}\right)$ and the PH and NGP $\left(r=0.526^{*}\right)$ in Table 10.

\section{Discussion}

\section{Grain yield}

Oats, among the small grains, is considered as are the plant species more tolerant to low soil $\mathrm{pH}$ values and high content of mobile Al compared to wheat (Đekić et al., 2018; Rajičić et al., 2019), as well as certain triticale genotypes (Đekić et al., 2014; Terzić et al., 2018; Rajičić et al., 2020). According to the authors Đekić et al. (2012), varieties of spring oats tested to low soil $\mathrm{pH}$ values show very good results. Based on the level of GY achieved, spring oat varieties are known to be the most tolerant, while according to the TGW and PC, the Vranac variety proved to be more adaptable.

All fertilizer variants tested achieved the highest average yield in 2016 and the lowest in 2017 (Tab. 2). According to the data of the Statistical office of the Republic of Serbia, the average GY of oats in 2015 was 2.7 $\mathrm{t} \mathrm{ha}^{-1}$, in $20163.0 \mathrm{t} \mathrm{ha}^{-1}$, while in 2017 it amounted to $2.4 \mathrm{t} \mathrm{ha}^{-1}$ (stat.gov.rs, 2020), which is in agreement with our results. A significant increase in GY in the second year of testing compared to the first and third years was due to the favourable effect of environmental factors, i.e. temperature and precipitation, on the yield components. Compared to the perennial average, rainfall in the second year of testing was significantly higher in May, which, with favourable temperatures, led to the formation of more grains per panicle and thus to higher yields. Significant deviation of precipitation and temperature from the perennial average in the Republic of Serbia is becoming more pronounced (Đekić et al., 2014; Popović et al., 2019). Namely, the total rainfall is reflected on a perennial average but the distribution, especially in the critical stages of development, is significantly disrupted (Đekić et al., 2018; Terzić et al., 2018; Rajičić et al., 2020).

Newly created high-yielding oat varieties have been found to be less responsive to temperature deviation than is the case with rainfall (Krishna et al., 2014; Szatanik-Kloc et al., 2019). Đekić et al. (2012), point out 
that intensive pre-harvest rainfall in 2006 led to crop lodging in case of Vranac and Lovcen cultivars, which reduced GY. Jelic et al. (2013), point out that the GY of oat grains varied significantly by years of research and amounted to $2.639 \mathrm{t} \mathrm{ha}^{-1}$ in 2008, while a much higher GY of $3.985 \mathrm{t} \mathrm{ha}^{-1}$ was established in 2010. Also, Dumlupinar et al. (2011), state that differences in GY between years occur due to environmental conditions. The same authors point out that statistically significantly higher GY was achieved on all fertilizer variants of the experiment compared to the non-fertilizer variant and that for all varieties the highest GY ( $\left.4.35 \mathrm{tha}^{-1}\right)$ was obtained on the fertilization variant with $90 \mathrm{~kg} \mathrm{~N} \mathrm{ha}^{-1}$. Mut et al. (2017), examining different oat genotypes over a two-year study, report that yields range from $2.432 \mathrm{t} \mathrm{ha}^{-1}$ to $5.650 \mathrm{t} \mathrm{ha}^{-1}$. Due to the rapid development of the root system, oats are more tolerant of spring drought than other spring cereals (Zielinski et al., 2017).

By analysing the results obtained, we can conclude that there is a significant dependence of GY on the year of study (Tab. 2), which is in agreement with the results of Jelic et al. (2013). In addition to genotype, GY of spring oats is greatly influenced by the fertilization system, which is one of the key factors, which affects the yield formed and its quality (Khan et al., 2014; Monjezi-Zadeh et al., 2018), but it needs to be aligned with climate and soil conditions as well as the requirements of the variety (Tomple and Hwan, 2018; Dumlupinar et al., 2019).

In Sumadija conditions, a very significant difference between the GY of oats and the year of the study has been found by Đekić et al. (2012). The research conducted by Jelic et al. (2013), in Western Serbia at the Rudno site indicate a significant influence of the growing season and a highly significant effect of fertilization on oat GY, which is explained by the high adaptability of the yield components to environmental conditions, especially in the third year of the study, which was characterized by favourable precipitation distribution. Genotype $\times$ environment interactions are responsible for most of the variation in GY in cereals and represent a significant possibility for increasing yield under certain agro-ecological conditions Dumlupinar et al. (2019).

Climate change has the potential to both positively and negatively affect the location, timing, and productivity of crop at local, national and global scales (Popović, 2015; Mihailović et al., 2020). Environmental law as a whole, and in particular the section on climate change, presents a complex challenge in various professional and scientific fields. The right of its instruments should help and improve solutions for overcoming the negative consequences of the complex problem of contemporary civilization in the field of climate change (Jovanović and Mihailović, 2020).

\section{0 grain weight}

The 1000 grain weight during the three-year study period was $28.54 \mathrm{~g}$. The values obtained are slightly higher than the TGW found by Jelic et al. (2013) and Kaziu et al. (2019), and lower than the results obtained by Tomple and Hwan (2018) and Dumlupinar et al. (2019). For the Solomom oat variety, over a three-year study, the TGW ranged from $23 \mathrm{~g}$ to $25.7 \mathrm{~g}$ (Sots and Kustov, 2014). Mut et al. (2017), examining different oat genotypes, stated that the TGW ranged from $24.5 \mathrm{~g}$ to $41.3 \mathrm{~g}$.

In Western Serbia, very significant differences between the TGW and the year of research have been found by Jelic et al. (2013), while highly significant differences in the conditions of Šumadija region have been found by Đekić et al. (2018). The same authors did not find any significant effect on the TGW between the tested nitrogen and phosphorus fertilization standards. Also, Jelic et al. (2013), Tomple and Hwan (2018) and Szatanik-Kloc et al. (2019), did not find a significant effect of nitrogen on the TGW, which is consistent with our research. However, Rajičić et al. (2020), point out that increased doses of nitrogen have a significant effect on reducing the TGW. Climatic conditions are especially important during grain loading, as lack of moisture and high temperature during this period influence the reduction of TGW (Dumlupinar et al., 2019), as confirmed by the results of these studies.

\section{Hectolitre weight}

The average three-year value of HW was the highest for the variant with combined application of NPK fertilizers with lime and manure $\left(43.70 \mathrm{kghl}^{-1}\right)$. The values obtained were slightly lower than the HW obtained 
by Jelic et al. (2013) and Đekić et al. (2018). A significant influence of the growing season on HW in oats is also established by Jelic et al. (2013). During a two-year study, Mut et al. (2017) have found that the HW of 25 oats genotypes tested ranged from 41.5 to $52.3 \mathrm{~kg} \mathrm{hl}^{-1}$. Many researchers have found a high dependence on different doses of nitrogen and phosphorus fertilizers, calcification and humification per HW (Jelic et al., 2013). The research conducted by Đekić et al. (2014), Terzić et al. (2018) and Rajičić et al. (2020), indicate that there is no significant correlation between $\mathrm{HW}$ and different fertilizer variants.

\section{Plant height}

Plant height is a direct component of resistance to crop lodging and an indirect component of GY and is one of the more important agronomic traits in oat breeding. More favourable conditions in 2016 caused higher average PH compared to 2015 and 2017. Batalova et al. (2010), point out the significant influence of the variety on the PL of oat, which ranged from $102.4 \mathrm{~cm}$ to $133.5 \mathrm{~cm}$. Examining 100 varieties of oats of world origin in Turkey, during a two-year study, Mut et al. (2016) conclude that the PH of oats ranges from 76.2 to $141.2 \mathrm{~cm}$. A significantly higher value of PH of oats is found by Kaziu et al. (2019). They state that the PH of oats during the study ranged from $118.5 \mathrm{~cm}$ to $160.4 \mathrm{~cm}$ between different genotypes. During a two-year study and examining of 25 oat genotypes, Mut et al. (2017), have found that the PH ranged from 76.3 to $128.3 \mathrm{~cm}$. Dumlupinar et al. (2019), have found significant variation in the PH of oats (from $46 \mathrm{~cm}$ to $112.7 \mathrm{~cm}$ ).

Although a cultivar trait, $\mathrm{PH}$ is not constant but susceptible to some degree of variation, which depends on the environmental influence under which the plants develop during the wilting phase (Batalova et al., 2010; Tomple and Hwan, 2018). The height of oat plants depends on genotype, agro-ecological conditions and agrotechnical measures (Surje and De, 2014; Mut et al., 2016; Dumlupinar et al., 2019; Kaziu et al., 2019). Significant influence of year and genotype on the PH of oats is obtained by Surje and De (2014), Mut et al. (2016) and Dumlupinar et al. (2019), while the significant influence of fertilization on PH is established by Mohr et al. (2012) and Tomple and Hwan (2018).

\section{Panicle length}

Panicle length in the studies conducted by Batalova et al. (2010) rand from $19.5 \mathrm{~cm}$ to $31.4 \mathrm{~cm}$. Kaziu et al. (2019), state that the PL across different oat genotypes ranged from $26 \mathrm{~cm}$ to $37.8 \mathrm{~cm}$ during the study, which is higher than our research. Tomple and Hwan (2018), point out that the maximum PL in both years of study $(2016,2017)$ is found in the fertilizer variant with $50 \mathrm{~kg} \mathrm{~N} \mathrm{ha}^{-1}(17.9 \mathrm{~cm}$ and $16.7 \mathrm{~cm})$. The same authors find a high dependence of PL on growing seasons and different nitrogen fertilization variants. Significant dependence of oat PL on genotype, year and their interactions were established by Dumlupinar et al. (2019).

\section{Number of grains per panicle}

The number of grains per panicle is the product of the number of spikelet and fertilized flowers per spikelet. Oat spikelet consists of 2 to 4 flowers. In facultative lines, the NGP depends mainly on the characteristics of the genotype and the sowing time (Mahadevana et al., 2016). The NGP for different oat genotypes ranges from 65 to 184 found by Dumlupinar et al. (2019), 94 to 159 found by Kaziu et al. (2019) and 95 to 174 per panicle for Batalova et al. (2010). Dumlupinar et al. (2019), cite a significant dependence of year, genotype, and their interaction on the NGP. After fertilization, which is highly dependent on environmental factors (temperature, humidity, light, etc.), germ is formed, then endosperm and finally, after a series of anatomic-morphological and biochemical changes in the crop, a grain is formed (Saccomanno et al., 2017).

\section{Protein content}

The chemical composition of the grain is one of the criteria for evaluating the quality of oats. Compared to wheat and barley, oat grain has a higher fat and cellulose content and a lower content of carbohydrates (Sterna et al., 2016). The chemical composition of the grain is controlled by the variety, climatic and soil 
conditions and cultivation technology. Proteins make up the bulk of organic nitrogen compounds in grains. Protein content of oats is very important, since proteins have great nutritional and biological value (Ahmad et al., 2011; Devi et al., 2019). One of the goals of oat breeding is the selection of genotypes with an increased share of essential amino acids, which play a significant role in human and animal nutrition (Jordanovska et al., 2018).

The average 3-year values of PC of oat grains varied between the fertilization treatments tested and ranged from $9.967 \%$ (T5) to $12.136 \%$ (T1). Mut et al. (2017), in the examination of different oat genotypes, state that PC ranges from 11.1 to $14.3 \%$. Panasiewicz et al. (2017), in the examination of different doses of nitrogen on PC in oat grains, have found that with increasing nitrogen dose, protein content increased. That is, the lowest PC is found for the variant without fertilization (11.13\%), compared to the variant with $50 \mathrm{~kg} \mathrm{~N}$ $\mathrm{ha}^{-1}(11.8 \%)$, while the highest PC in the oat grain is found in the variant with $150 \mathrm{~kg} \mathrm{~N} \mathrm{ha}^{-1}$ (14.5\%). For different fertilization variants, Monjezi-Zadeh et al. (2018), have found that the PC of oat grains ranged from $10.38 \%$ to $11.72 \%$. Examining the effect of calcification and humification on PC of oat grains Jelic et al. (2013) state that it ranged from $10.17 \%$ to $12.04 \%$. Jordanovska et al. (2018), point out that the PC of different oat varieties ranged from $11.99 \%$ to $14.62 \%$, which is significantly higher than our results. Jelic et al. (2013), by regular use of NPK fertilizers with an increased content of phosphorous nutrient and combined application of NPK, lime and manure, have established the wheat grain higher in PC than control.

The research conducted by Jelic et al. (2013), indicate a highly significant influence of the growing season and fertilization on the PC of oat grains, which is in agreement with our research. Also, Dumlupinar et al. (2011), highlight the significant impact of the growing season and cultivar on PC of oat grains. Panasiewicz et al. (2017), find that there is no significant relationship between PC in oat grains and applied doses of nitrogen, although with increasing nitrogen doses PC increases. Many authors have found a highly significant effect of mineral nutrition and liming on the chemical composition of oat grains, and especially on PC (Mut et al., 2016; Panasiewicz et al., 2017; Monjezi-Zadeh et al., 2018; Jordanovska et al., 2018).

\section{Correlations between the analysed traits}

A strong positive correlation between small GY and TGW has been found by many researchers (Krishna et al., 2014; Terzic et al., 2018), medium (Jelic et al., 2013; Đekić et al., 2014, Güngör et al., 2017), while weak positive dependence has been identified by Vaisi and Golparvar, (2013). Positive and weak dependence of GY and TGW ( $\mathrm{r}=0.35)$ was found by Dumlupinar et al. (2012). Kaziu et al. (2019), found a weak negative and significant relationship between oat GY and TGW ( $\mathrm{r}=-0.29)$. Mut et al. (2017), found a highly significant and positive correlation between GY and TGW $\left(\mathrm{r}=0.25^{*}\right)$. The duration of the grain filling period is significantly influenced by environmental factors, above all the high temperatures that shorten this period (Güngör et al., 2017). Selection of early-flowering genotypes can influence the formation of more flowers and a longer grain filling period, i.e. the selection of higher yielding genotypes (Mut et al., 2018).

Many researchers have found weak positive correlations between small grain yields and HW of different fertilizer variants (Terzic et al.2018; Rajičić et al.2019). A significant and negative correlation between the GY of oats and $\mathrm{HW}$ in the variant with $80 \mathrm{~kg} \mathrm{~N} \mathrm{ha}^{-1}\left(\mathrm{r}=-0.64^{*}\right)$ and in the variant with NPK, lime and manure ( $\mathrm{r}=-$ $0.55^{\circ}$ ) has been established by Jelic et al. (2013). The same authors have found a highly significant positive correlation between GY and HW by humification $\left(\mathrm{r}=0.79^{\prime \prime}\right)$. Negative and significant dependencies of TGW and HW at different fertilization rates with nitrogen and phosphorus have been found by Đekić et al. (2014). Mut et al. (2017), over a two-year trial, have found a positive correlation between GY and HW ( $r=0.246)$.

Analysing the interdependence of GY and PH, Krishna et al. (2014) and Shah et al. (2015), state that their correlation is positive and, depending on the material examined, ranges from weak to strong. A highly significant positive correlation between GY and PH is found by Surje and De (2014). A positive and significant correlation between the GY and PH of oats is determined by Mut et al. (2016) and Dumlupinar et al. (2019). Contrary to these authors, a weak negative correlation between GY and PH of oats is found by Dumlupinar et al. (2012) ( $\left.\mathrm{r}=-0.28^{*}\right)$, Güngör et al. (2017) ( $\left.\mathrm{r}=-0.38\right)$ and Kaziu et al. (2019) ( $\left.\mathrm{r}=-0.23\right)$. Based on the results of 
their research, Dumlupinar et al. (2019), conclude that, even if there is no direct correlation between PH and GY, a decrease in plant height may influence the increase in yield indirectly, by increasing the TGW or increasing the resistance to crop lodging.

Based on the results of the correlation coefficients, Dumlupinar et al. (2012), point out that the $\mathrm{PH}$ is significantly positively correlated with the NGP $\left(\mathrm{r}=0.281^{*}\right)$, which is in agreement with our study. Positive correlations between PH of oats and PL ( $r=0.384)$ and TGW ( $r=0.116)$, PL and NGP $(r=0.586)$ are found by Krishna et al. (2014). A significant dependence of the PH of oats with the NGP $\left(\mathrm{r}=0.188^{*}\right)$, TGW $\left(\mathrm{r}=0.188^{*}\right)$ and $\mathrm{GY}\left(\mathrm{r}=0.155^{\circ}\right)$ and highly significant between $\mathrm{PH}$ and $\mathrm{PL}$ is found by Dumlupinar et al. (2019). Significantly positive correlation between the NGP and the PH $\left(r=0.60^{*}\right)$ and between the NGP and PL $\left(\mathrm{r}=0.71^{*}\right)$ in oats is obtained by Batalova et al. (2010). A highly significant dependence in oats between the NGP and PL $\left(\mathrm{r}=0.57^{*}\right)$, NGP and TGW ( $\left.\mathrm{r}=-0.79^{*}\right)$ and NGP and GY $\left(\mathrm{r}=0.78^{*}\right)$ is found by Kaziu et al. (2019).

\section{Conclusions}

The method proposed by the present study for the evaluation of the distribution of fertilizers on oats was practical and efficient. The influence of different fertilization variants of NPK with nutrition, calcification and humification on the GY and yield components of oats in different growing seasons is analysed in the paper. Grain yield and quality were the best in the 2016 growing season, due to the favourable rainfall distribution, which favourably affected the production of oats, while the worst quality was established in 2017 . The obtained results show a high effect of combined application of NPK fertilizers with lime and manure on GY and some parameters of its quality. The highest average three-year GY of oats was found in the fertilizer variant with combined application of NPK, lime and manure $\left(3.802 \mathrm{t} \mathrm{ha}^{-1}\right)$, and the lowest in the non-fertilizer variant $\left(1.119 \mathrm{t} \mathrm{ha}^{-1}\right)$. The application of this treatment resulted in a significant increase in GY and in particular increased grain quality parameters, especially protein content. The impact of climatic factors on the yield components and quality of oat grains was highly significant. The highly significant effect of fertilization on GY, PC of the grain, PH, PL, and NBP were determined. Highly significant positive correlation coefficients between HW and GY, PL and NBP were found in the fertilizer variant with NPK, lime and manure.

The results of the study indicate the importance of calcification and humification on the yield and yield components of oats, thereby reducing soil acidity, increasing yield and improving quality, which favourably affects more profitable production of oats.

\section{Authors' Contributions}

All authors have participated in this research. VR has designed, supervised and written the paper; DG, $M D$ and MG have participated in the experimentation and sample collection; VP, AM and VU have analysed the data obtained; VR, VP and DT have overseen the project and revised the manuscript. All authors have read and approved the final manuscript.

\section{Acknowledgements}

Ph.D. Vera Rajičić sincerely thanks to the secondary agricultural-chemical school "PhD Đorđe Radić" in Kraljevo in Serbia, which has enabled the use and analysis of traits of the oats. Investigations necessary for this paper are part of the Projects agreement number 451-03-68/2020-14/200383, 200189 and 200011; financed by the Ministry of Education, Science and Technology Development of Republic of Serbia. and Bilateral Project Serbia MNO, 2019-2020: Alternative cereals and oil crops as a source of healthcare food and 
an important raw material for the production of biofuel; and FAO Project, 2020-2022: GRAINeFIT BSF-4 project.

\section{Conflict of Interests}

The authors declare that there are no conflicts of interest related to this article.

\section{References}

Ahmad AH, Wahid A, Fiaz N, Zamir M (2011). Impact of organic and inorganic sources of nitrogen and phosphorus fertilizers on growth, yield and quality of forage oat (Avena sativa L.). Cercetari Agronomice in Moldova 44:3949. https://doi.org/10.2478/v10298-012-0040-7

Amanullah J, Stewart BA (2013). Dry matter partitioning, growth analysis and water use efficiency response of oats (Avena sativa L.) to excessive nitrogen and phosphorus application. Journal of Agricultural Science and Technology 15:479-489. https://www.sid.ir/en/journal/ViewPaper.aspx?ID=302977

Batalova GA, Changzhong R, Rusakova II, Krotova NV (2010). Breeding of naked oats. Russian Agricultural Sciences 36:93-95. https://doi.org/10.3103/S1068367410020059

Brunava L, Alsina I, Zute S, Sterna V, Vicupe Z (2014). Some chemical, yield and quality properties of domestic oat cultivars. In: Proceedings of the 9th Baltic Conference on Food Science and Technology "Food for Consumer $\begin{array}{llll}\text { Well-being" } & \text { FOODBALT } & \text { pp }\end{array}$ http://llufb.llu.Iv/conference/foodbalt/2014/FoodBalt_Proceedings_2014.pdf

Đekić V, Staletić M, Milivojević J, Popović V, Jelić M (2012). Nutritive value and yield of oat grain (Avena sativa L.). Agroznanje 13(2):217-224. https://www.cabdirect.org/cabdirect/abstract/20133205381

Đekić V, Milovanović M, Popović V, Milivojević J, Staletić M, Jelić M, Perišić V (2014). Effects of fertilization on yield and grain quality in winter triticale. Romanian Agricultural Research 31:175-183. http://www.incdafundulea.ro/rar/nr31/rar31.22.pdf

Đekić V, Jelić M, Popović V, Terzić D, Đurić N, Grčak D, Grčak M (2018). Parameters of grain yield and quality of spring oats. Proceedings of the Journal of PKB Agroekonomik Institute 24(1-2):81-86.

Devi U, Panghaal D, Kumar P, Sewhag M, Kumar P (2019). Effect of nitrogen fertilizers on yield and quality of oats: A Review. International Journal of Chemical Studies 7(2):1999-2005. http://www.chemijournal.com/archives/2019/vol7issue2/PartAH/7-2-440-976.pdf

Dumlupinar Z, Maral H, Kara R, Dokuyucu T, Akkaya A (2011). Evaluation of Turkish oat landraces bases on grain yield, yield components and some quality traits. Turkish Journal of Field Crops 16:190-196. https://www.researchgate.net/publication/257930629

Dumlupinar Z, Kara R, Dokuyucu T, Akkaya A (2012). Correlation and path analysis of grain yield and yield components of some Turkish oat genotypes. Pakistan Journal of Botany 44(1):321-325. https://www.researchgate.net/publication/237826720

Dumlupinar Z, Güngör H, Dokuyucu T, Herek S, Tekin A, Akkaya A (2019). Agronomical screening of OGLE1040/TAM O-301 oat genetic mapping population. Sains Malaysiana 48(5):975-981. http://dx.doi.org/10.17576/jsm-2019-4805-05

FAOSTAT (2020). Retrieved April 5, 2020 from http://faostat.fao.org

GenStat Release 16.2 (PC/Windows 7) (2013). GenStat Procedure Library. Release PL24.2. VSN International Ltd. Rothamsted, UK.

Güngör H, Dokuyucu T, Dumlupinar Z, Akkaya A (2017). Yulafta (Avena spp.) Tane Verimi ile Bazı Tarımsal Özellikler Arasındaki İlişkilerin Korelasyon ve Path Analizleriyle Saptanması. Tekirdağ Ziraat Fakültesi Dergisi 14(01):6168. http://acikerisim.nku.edu.tr:8080/xmlui/handle/20.500.11776/2136

Jelic M, Dugalić G, Milivojević J, Đekić V (2013). Effect of liming and fertilization on yield and quality of oat (Avena sativa L.) on an acid luvisol soil. Romanian Agricultural Research 30:249-258. http://www.incdafundulea.ro/rar/nr30/rar30.32.pdf 
Jelic M, Milivojevic J (2015). Gvožđe, mangan, cink i alumijim u kiselim zemljištima Centralne Srbije./Iron, manganesse, zinc and aluminium at acid soils of Central Serbia. University of Priština, Faculty of Agriculture, Lešak, Serbia.

Jovanović Lj, Mihailović A (2020). Environmental protection: right and obligation. Gea International Conference 2020, Podgorica, Montenegro, pp 190-199.

Jordanovska S, Jovović Z, Dolijanović Ž, Dragiĉević V, Branković G, Đekić V (2018). Nutritional properties of macedonian landraces of small grain cereals as a source of new genetic variability. Genetika 50(3):863-883. https://doi.org/10.2298/GENSR1803863J

Kaziu I, Kashta F, Celami A (2019). Estimation of grain yield, grain components and correlations between them in some oat cultivars. Albanian Journal of Agricultural Sciences 18(1):13-19. https://search.proquest.com/openview/7901a13c9734a558e941015262a19977/1?pqorigsite $=$ gscholar\&cbl $=1316365$

Khan A, Anjum MH, Rehman MKU, Zaman Q, Ullah R (2014). Comparative study on quantitative and qualitative characters of different oat (Avena sativa L.) genotypes under agro-climatic conditions of Sargodha, Pakistan. American Journal of Plant Sciences 5:3097-3103. https://doi.org/10.4236/ajps.2014.520326

Krishna A, Ahmed S, Pandey HC, Kumar V (2014). Correlation, path and diversity analysis of oat (Avena sativa L.) genotypes for grain and fodder yield. Journal of Plant Science \& Research 2:1-9. https://www.researchgate.net/profile/Shahid_Ahmed27/publication/

Mahadevana M, Calderini DF, Zwera PK, Sadrasa VO (2016). The critical period for yield determination in oat (Avena sativa L.). Field Crops Research 199:109-116. https://doi.org/10.1016/j.fcr.2016.09.021

Maral H, Dumlupinar Z, Dokuyucu T, Akkaya A (2012). Impact of genotype and nitrogen fertilizer rate on yield and nitrogen use by oat (Avena sativa L.) in Turkey. Turkish Journal of Field Crops 17(2):177-184. https://dergipark.org.tr/en/download/article-file/158684

Maral H, Dumlupinar Z, Dokuyucu T, Akkaya A (2013). Response of six oat (Avena sativa L.) cultivars to nitrogen fertilization for agronomical traits. Turkish Journal of Field Crops 18(2):254-259. https://dergipark.org.tr/en/download/article-file/158649

Mihailović A, Jovanović Lj, Rajičić V (2020). Climate change as a threat to global economy. Gea International Conference 2020, Podgorica, Montenegro, pp 190-199.

Monjezi-Zadeh M, Roshanfekr H, Hassibi P, Sorkhi B (2018). Evaluation effect of macro and micro nutritional elements on quantitative and qualitative characteristics of oat crop (Avena sativa L.). Journal of Crop Nutrition Science 4(1):33-46. https://iranjournals.nlai.ir/1965/pdf_493260_20655178c85634239ece1a2b2fedde6f.html

Mut Z, Erbaş Kose ÖD, Akay H (2016). Grain yield and some quality traits of different oat (Avena sativa L.) genotypes. International Journal of Environmental \& Agriculture Research 2(12):83-88. https://ijoear.com/PaperDecember-2016/IJOEAR-DEC-2016-16.pdf

Mut Z, Kose Ö, Akay H (2017). Grain yield and some quality traits of different oat Avena sativa L. genotypes. Journal of Agronomy and Agricultural Aspects 108. https://www.gavinpublishers.com/articles/research-article/Journal-ofAgronomy-and-Agricultural-Aspects-ISSN-2574-2914/grain-yield-and-some-quality-traits-of-different-oatavenaSativaL-genotypes

Mut Z, Akay H, Köse O (2018). Grain yield, quality traits and grain yield stability of local oat cultivars. Journal of Soil Science and Plant Nutrition 18(1):269-281. http://dx.doi.org/10.4067/S0718-95162018005001001

Nawaz MQ (2017). Effect of different sowing methods and nitrogen levels on fodder yield of oat in salt affected soil. Pakistan Journal of Agricultural 30(4):323-328. http://dx.doi.org/10.17582/journal.pjar/2017/30.4.323.328

Panasiewicz K, Koziara W, Sulewska H, Chrzanowski R (2017). Chemical composition and nutritive value of different oat forms as influence by sprinkling irrigation and nitrogen fertilization. Romanian Agricultural Research 34:157164. http://www.incda-fundulea.ro/rar/nr34/rar34.19.pdf

Popović V, Stevanović P, Vučković S, Ikanović J, Rajičić V, Bojović R, Jakšić S (2019). Influence of CAN fertilizer and seed inoculation with NS Nitragin on Glycine max plant on pseudogley soil type. Agriculturae Conspectus Scientificus 84(2):165-171. https://hrcak.srce.hr/221760

Rajičić V, Milivojević J, Popović V, Branković S, Đurić N, Perišić V, Terzić D (2019). Winter wheat yield and quality depending on the level of nitrogen, phosphorus and potassium fertilization. Agriculture and Forestry 65(2):79-88. https://doi.org/10.17707/AgricultForest.65.2.06 
Rajičić V, Popović V, Perišić V, Biberdžić M, Jovović Z, Gudžić N, ... Terzić D (2020). Impact of nitrogen and phosphorus on grain yield in winter triticale grown on degraded Vertisol. Agronomy 10(6):757. https://doi.org/10.3390/agronomy10060757

Saccomanno B, Chambers AH, Hayes A, Mackay I, Mc William SC, Trafford K (2017). Starch granule morphology in oat endosperm. Journal of Cereal Science 73:46-54. https://doi.org/10.1016/j.jcs.2016.10.011

Shah SAS, Akhtar LH, Minhas R, Bukhari MS, Ghani A, Anjum MH (2015). Evaluation of different oat (Avena sativa L.) varieties for forage yield and related characteristics. Science Letters 3(1):1316. https://pdfs.semanticscholar.org/d763/1c43ee125ab1c5fe42e2d86f1da005976346.pdf

Sots SM, Kustov IO (2014). Evaluation of some technological factors of Ukrainian naked oats and barley affecting on its processing to food products. Scientia Agriculturae 8(1):50-59. https://doi.org/10.15192/PSCP.SA.2014.4.1.5059

Statistical Office of the Republic of Serbia (2020). Agriculture, forestry and fishery. Retrieved April 5, 2020 from http://opendata.stat.gov.rs

Sterna V, Zute S, Brunava L (2016). Oat grain composition and its nutrition benefice. Agriculture and Agricultural Science Procedia 8:252-256. https://doi.org/10.1016/j.aaspro.2016.02.100

Surje DT, De DK (2014). Correlation coefficient study in oat (Avena sativa L.) genotypes for fodder and grain yield characters. Journal Agriculture Science $\quad$ Technology 1(1):89-93. https://www.researchgate.net/profile/Dinesh_Surje/publication/303073153.pdf

Szatanik-Kloc A, Ambrożewicz-Nita A, Franus W, Józefaciuk G (2019). Early effect of clinoptilolite on yield and quality of oat (Avena sativa L.). International Agrophysics 33:107-112. https://doi.org/10.31545/intagr/104411

Terzić D, Đekić V, Jevtić S, Popović V, Jevtić A, Mijajlović J, Jevtić A (2018). Effect of long-term fertilization on grain yield and yield components in winter triticale. JAPS: Journal of Animal \& Plant Sciences 28(3):830-836. Available online: http://www.thejaps.org.pk/docs/v-28-03/19.pdf

Tomple BM, Hwan JI (2018). Enhancing seed productivity and feed value of oats (Avena sativa L.) with different seeding rate and nitrogen fertilizing levels in Gyeongbuk area. Journal of Agriculture \& Life Science 52(6):61-72. http://jals.gnu.ac.kr/journal/article.php?'code $=64622$

Vaisi H, Golparvar AR (2013). Determination of the best indirect selection criteria to improve grain yield and seed weight in oat (Avena sativa L.) genotypes. International Journal of Farming and Allied Sciences 2:74750. http://www.ijfas.com/wp-content/uploads/2013/10/747-750.pdf

Vasileva V, Kostov O (2018). Performance of oats (Avena sativa) in response to preceding alfalfa (Medicago sativa) on mineral fertilization versus organic manuring on Chernozem soil. Indian Journal of Agricultural Sciences 88(3):416-419. http://epubs.icar.org.in/ejournal/index.php/IJAgS/article/view/78517

Zielinski A, Mos M, Wójtowicz T (2017). In vivo evaluation of vigor in naked and husked oat cultivars under drought stress conditions. Chilean Journal of Agricultural Research 77(2):110-117. http://dx.doi.org/10.4067/S071858392017000200110
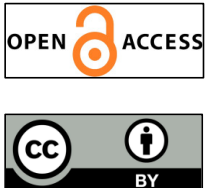

The journal offers free, immediate, and unrestricted access to peer-reviewed research and scholarly work. Users are allowed to read, download, copy, distribute, print, search, or link to the full texts of the articles, or use them for any other lawful purpose, without asking prior permission from the publisher or the author.

License - Articles published in Notulae Botanicae Horti Agrobotanici Cluj-Napoca are Open-Access, distributed under the terms and conditions of the Creative Commons Attribution (CC BY 4.0) License. (c) Articles by the authors; UASVM, Cluj-Napoca, Romania. The journal allows the author(s) to hold the copyright/to retain publishing rights without restriction. 